\title{
USE OF ASPIRIN IN HAEMORRHAGIC SHOCK
}

\author{
Christopher E. Famewo, William H. Noble, and M. Bernadette Garvey
}

Platelet adhesiveness and aggregation have been observed by many authors to increase during haemorrhagic shock. ${ }^{1-3}$ The increased platelet aggregation predisposes to platelet micro-emboli and this has been offered as an explanation for the increased pulmonary vascular resistance (PVR) observed in haemorrhagic shock. ${ }^{4,5}$

Aspirin reduces platelet adhesiveness and collagen-induced aggregation without affecting other coagulation factors, ${ }^{6.7}$ an advantage over heparin when used in patients with massive trauma. Aspirin is readily available and relatively innocuous in the small doses required to affect platelet function. The effect of aspirin on platelet function lasts about eight days after ingestion in human subjects. ${ }^{8}$

This study was performed to determine if aspirin could affect the elevated PVR observed following retransfusion of blood in haemorrhagic shock.

\section{METHOD}

Two similar groups of dogs 'weighing between 16 and $22 \mathrm{Kg}$ were studied. There were five dogs in each group. Anaesthesia was induced with intravenous (I.V.) pentobarbitone $30 \mathrm{mg} / \mathrm{Kg}$, after which one group received four to six tablets (1.2 to $1.8 \mathrm{gm})$ of aspirin while the other group did not receive aspirin. An intravenous form of aspirin was not available and the aspirin was given through a stomach tube. (Since completion of this study an intravenous preparation of aspirin has been obtained and will be used in further studies.)

Absorption though poorer in shock was adequate for the small blood concentration required to affect the platelet function.

Catheterization: Pulmonary artery (PA), femoral artery, left atrium (LA) and central venous pressure (CVP) catheters were passed (Figure 1). The positions were determined by pressure monitoring and, in the case of the LA catheter, visually confirmed anatomically at the end of the experiment. No heparin was used in the infusion lines, which were kept patent by regular flushing with normal saline (average $1,000 \mathrm{cc}$. over eight hours).

Format of Experiment: The experiment was divided into four stages: (a) preshock, $(b)$ shock, $(c)$ retransfusion, and $(d)$ bicarbonate administration. Shock was inducd by bleeding the dogs to a mean arterial pressure (MAP) of between 40 and $50 \mathrm{~mm} / \mathrm{Hg}$. They were maintained at this pressure for two hours and were then retransfused with their own blood. Blood was collected into ACD bags and reinfused through regular blood-giving sets.

The following measurements were made at each of the four stages of the experiment: 1, mean arterial pressure (MAP); 2, central venous pressure (CVP);

\footnotetext{
Departments of Anaesthesia and Haematology, St. Michael's Hospital and University of Toronto, Toronto, Ontario, Canada.
} 


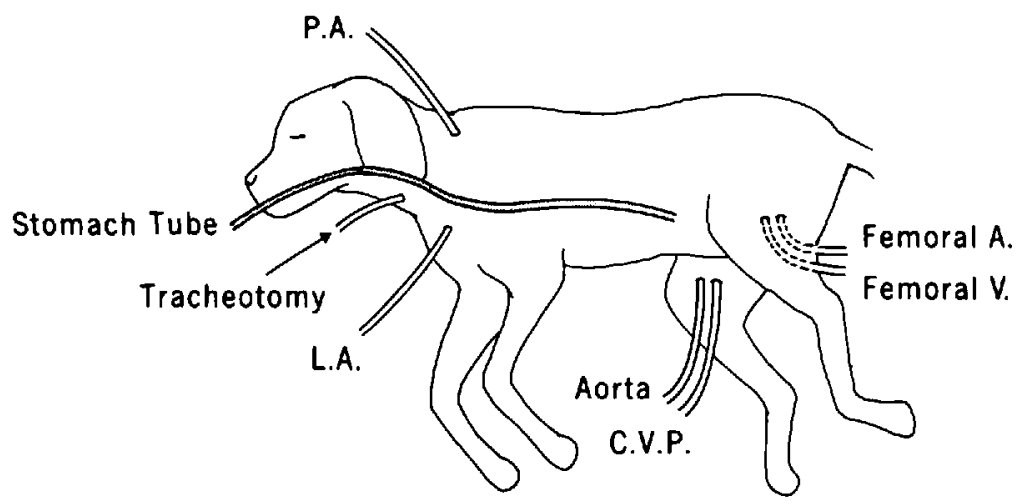

Ficure 1. Dog showing cannulation of pulmonary artery (PA), left atrium (LA), aorta, femoral artery and vein, CVP, stomach and trachea.

3 , left atrial (LA) pressure; 4, pulmonary artery (PA) pressure; 5 , cardiac output $(\dot{Q}) ; 6$, lung water $\left(\operatorname{ETV}_{\mathrm{L}}\right) ; 7$, blood gases (arterial and mixed venous); 8, expired $\mathrm{O}_{2}$ and $\mathrm{CO}_{2} ; 9$, salicylate blood level; 10 , complete coagulation screen, including an assay of individual coagulation factors. Platelet aggregation was measured using a Payton aggregometer and Bausch and Lomb recorder.

The lung water and cardiac output were determined by a thermodilution technique. ${ }^{9}$ From these measurements the following were derived:

1. Pulmonary Vascular Resistance

$$
\left[\mathrm{PVR}=\frac{(\mathrm{PA}-\mathrm{LA}) \times 1332}{\dot{\mathrm{Q}}} \text { dynes. sec. } \mathrm{cm}^{-5}\right]
$$

2. Systemic Vascular Resistance

$$
\left[\mathrm{SVR}=\frac{(\mathrm{MAP}-\mathrm{CVP}) \times 1332}{\bar{Q}} \text { dynes. sec. } \mathrm{cm}^{-5}\right]
$$

3. Dead space ratio (VD/VT), and

4. Shunt fraction ( $\dot{\mathrm{Q}} / \dot{\mathrm{Q} T}$ ).

\section{RESULTS}

All pressures and cardiac output $(\dot{Q})$ fell during shock. After blood was reinfused the $\dot{Q}$ and MAP returned to near preshock values. The percentage increase in lung water after retransfusion in the control group was 25 per cent, but only 14 per cent in the aspirin group.

During shock, mean PVR rose five-fold in the aspirin group and seven-fold in the control group. Following blood retransfusion, the PVR returned to baseline value in the aspirin group, but remained at twice the baseline value in the control group (Figures 2 and 3 ). This difference is statistically significant $(p<0.01$ ). 


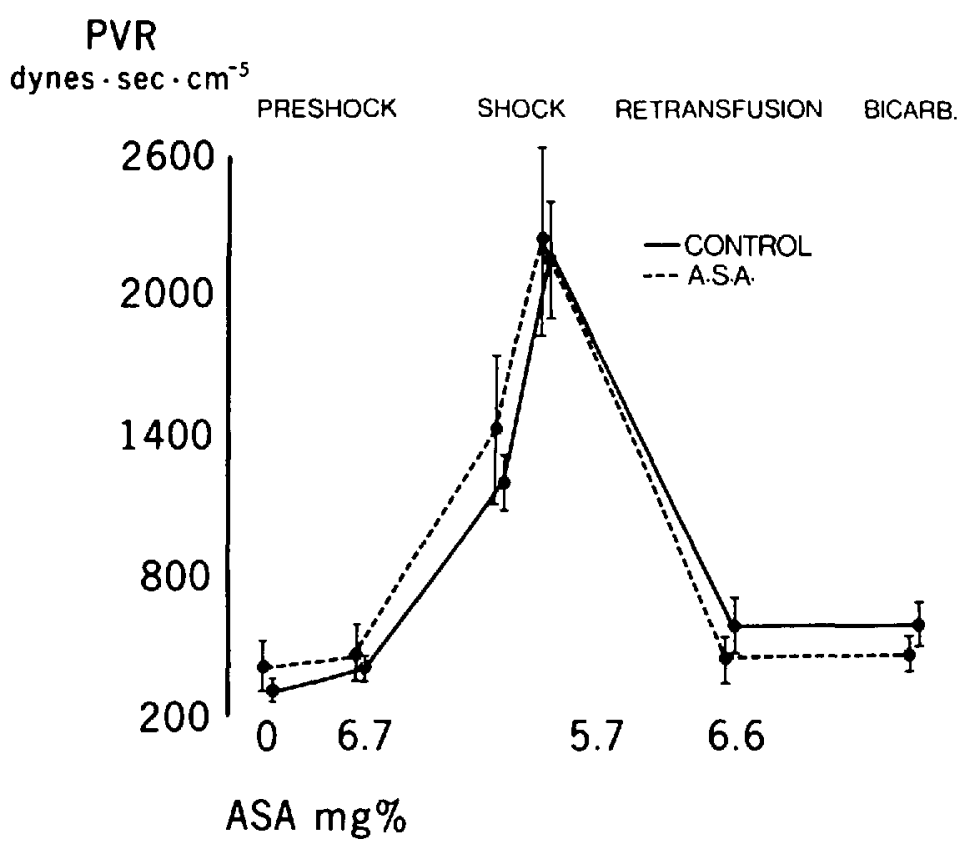

FIcure 2. Changes in pulmonary vascular resistance (PVR) and the blood levels of salicylate (ASA) are shown at the different stages of the experiment.

Correction of base deficit with bicarbonate did not return the PVR to the baseline value, indicating that acidosis is not the cause of the elevated PVR in the control group at this stage.

SVR rose markedly during shock but returned to baseline values after retransfusion in both aspirin and control groups.

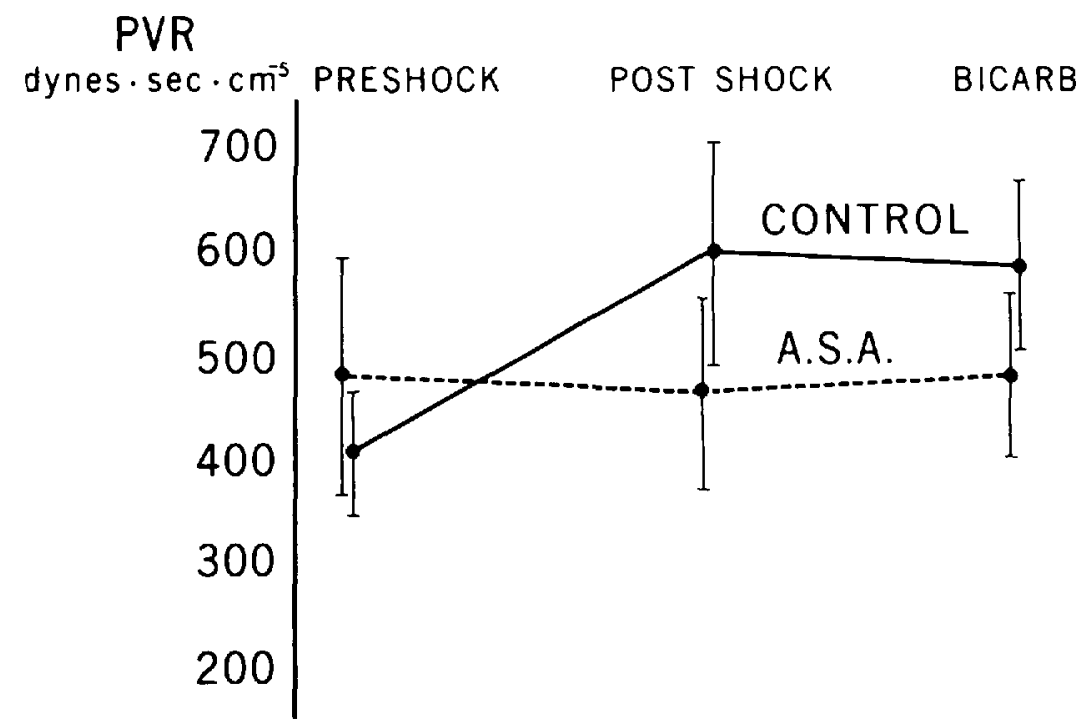

Figure 3. Pulmonary vascular resistance (PVR) returned to pre-shock value after retransfusion of blood in the aspirin group but remained elevated at twice the pre-shock value in the control group. 
TABLE I

Post Trangfusion State

\begin{tabular}{lcc}
\hline \hline & Aspirin Group & Control Group \\
\hline $\mathrm{PaO}_{2}$ & $102.5 \pm 4.2$ & $83.1 \pm 3.3$ \\
$\mathrm{PaCO}_{2}$ & $28.9 \pm 2.8$ & $39.7 \pm 3.6$ \\
$\dot{Q} / \mathrm{QT}$ & $0.23 \pm 0.02$ & $0.30 \pm 0.08$ \\
$\mathrm{VD} / \mathrm{VT}$ & $0.42 \pm 0.07$ & $0.68 \pm 0.03$ \\
\hline
\end{tabular}

Mean Values of $\mathrm{PaO}_{2}, \mathrm{PaCO}_{2}, \dot{\mathrm{Q}} \mathrm{S} / \dot{\mathrm{Q} T}$, and VD/VT \pm 1 S.D.

After retransfusion the aspirin group had a higher $\mathrm{PaO}_{2}$ and a lower $\mathrm{PaCO}_{2}$ when compared with the control group. The shunt fraction (QS/QT) and dead space ratio (VD/VT) were also smaller in the aspirin group (as shown in Table I).

Both aspirin and control groups developed a similar degree of metabolic acidosis in late shock ( $\mathrm{pH} 7.0$ with $\mathrm{BE}-21$ ). After blood was reinfused, the control group became less acidotic ( $\mathrm{pH} 7.18$ with $\mathrm{BE}-14$ ) while the aspirin group remained relatively unchanged $(\mathrm{pH} 7.045$ with $\mathrm{BE}-22$ ) (Figure 4). Salicylate levels were between 5 and $8 \mathrm{mg}$ per cent. Coagulation Studies showed that individual coagulation factors, Prothrombin Time (PT) and Partial Thromboplastin Time (PTT) were unaffected by administration of aspirin. However, after shock was induced, there was prolongation of the PT and PTT with the appearance of FDP (Fibrinogen Degradation Products) in both the aspirin and control groups (Figure $5(\mathrm{a})-(\mathrm{g}))$. This is consistent with the development of Disseminated Intravascular Coagulation (DIC) during haemorrhagic shock. Platelet aggregation: Collagen-induced platelet aggregation was consistently absent after aspirin administration (Figure 6).

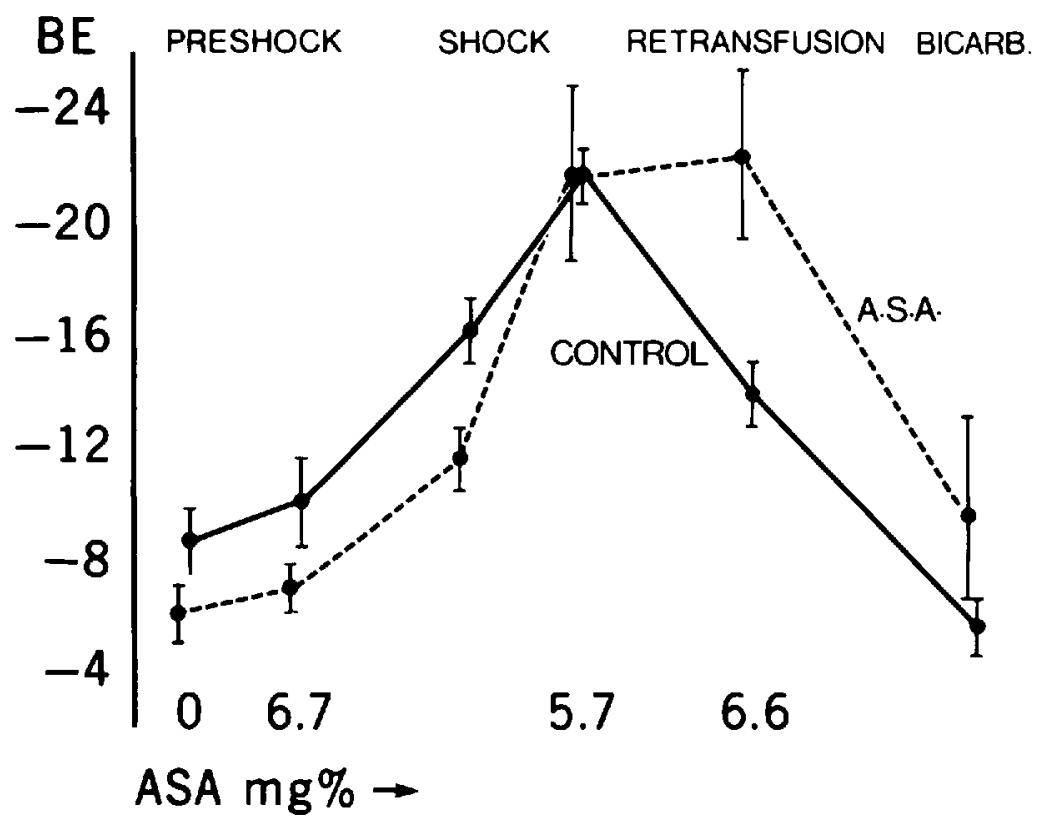

Frcure 4. Changes in base excess (BE) during the different stages of the experiment. 
FACTOR V

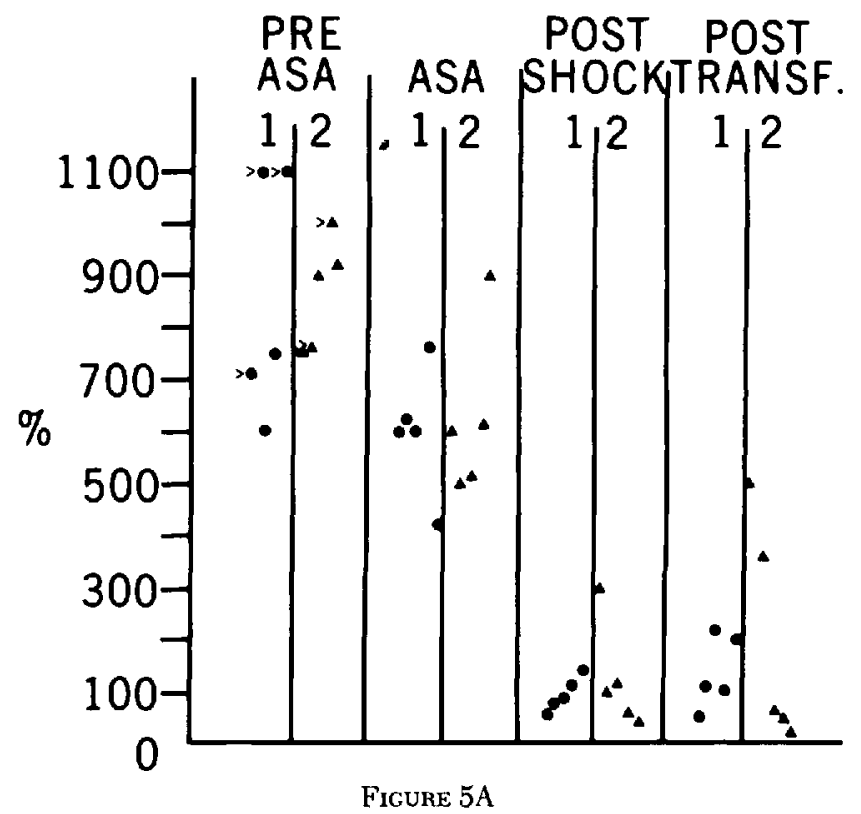

Ficune 5. (a) to ( $g$ ) Changes in factors V, VIII, PT, PTT, TT, fibrinogen time, FDP latex during the four stages of the experiment. represents controls, $\triangle$ represent ASA.

FACTOR VIII

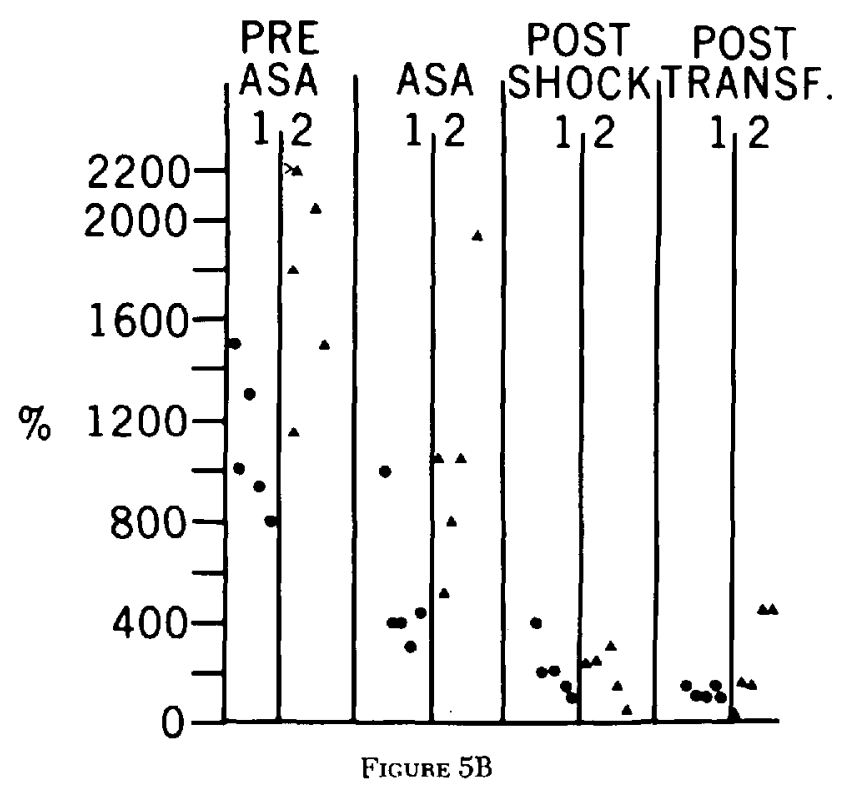


FAMEWO, et $a l$ : ASPIRIN IN HAEMORRHAGIC SHOCK

PROTHROMBIN TIME

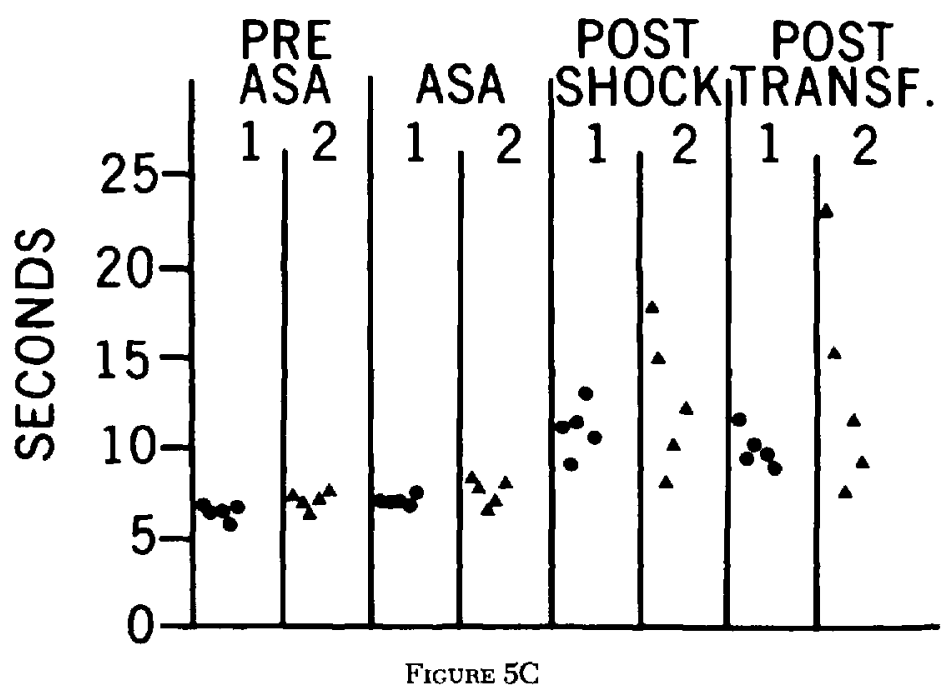

P.T.T.

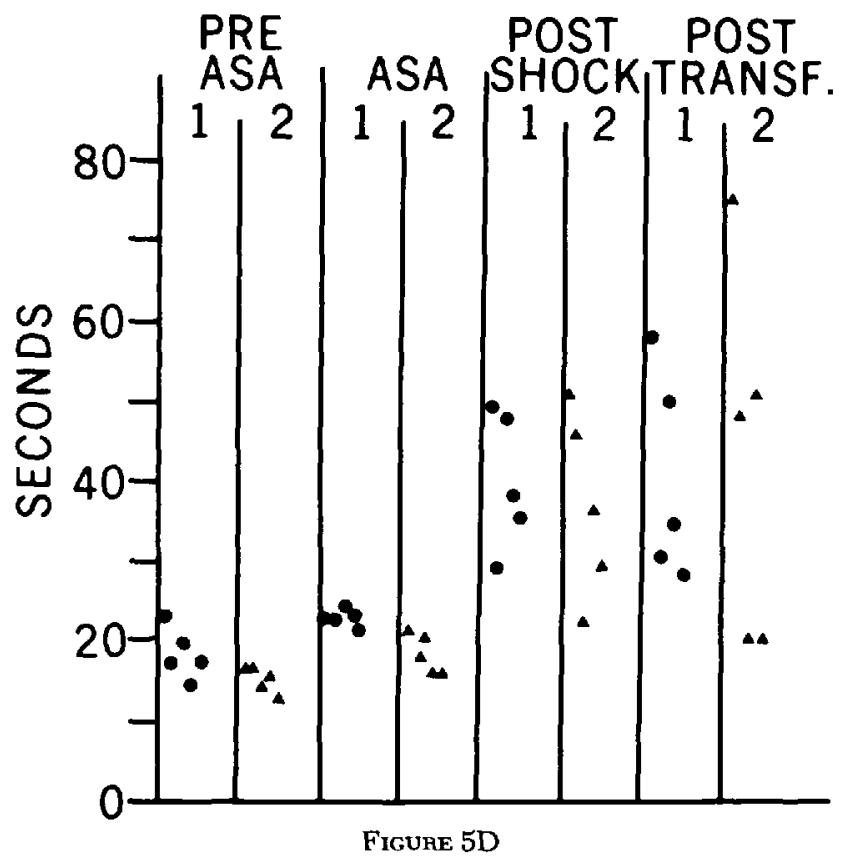


THROMBIN TIME

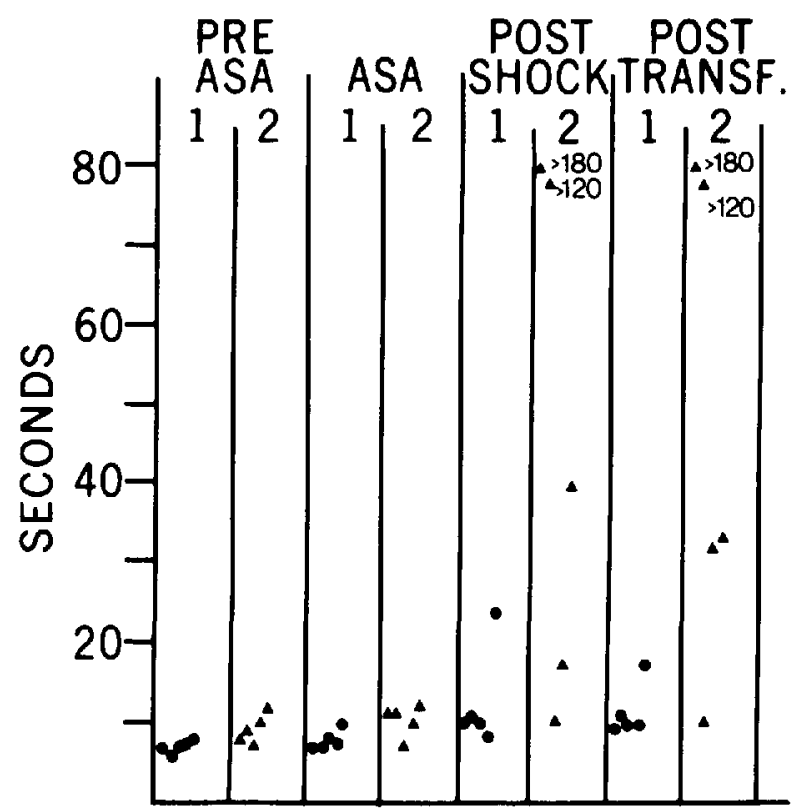

Figure 5E

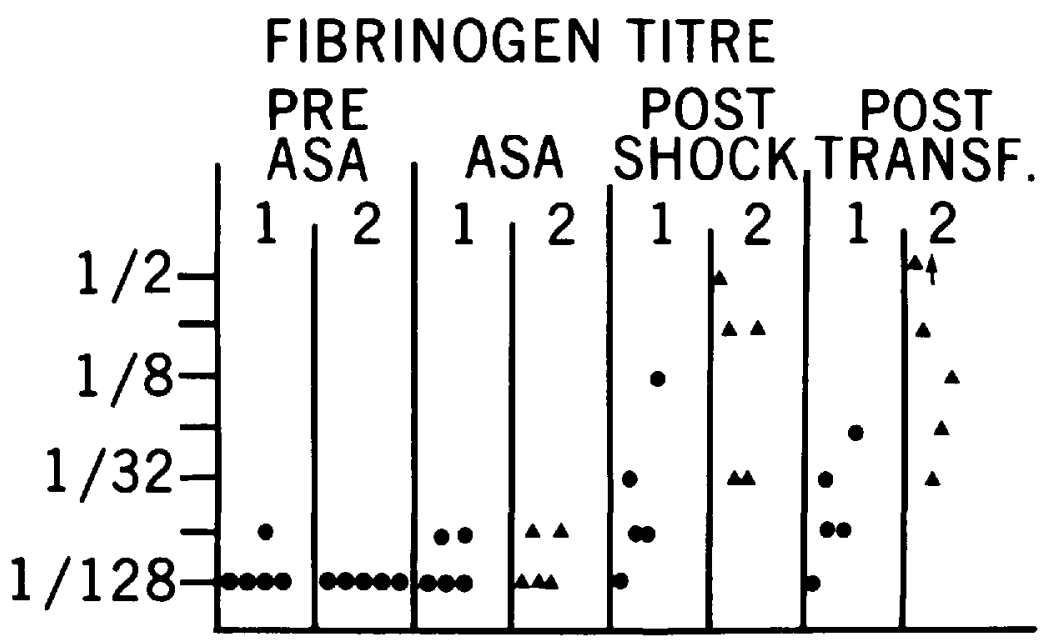

Figure 5F 
FAMEWO, et al.: ASPIRIN IN HAEMORRHAGIC SHOCK
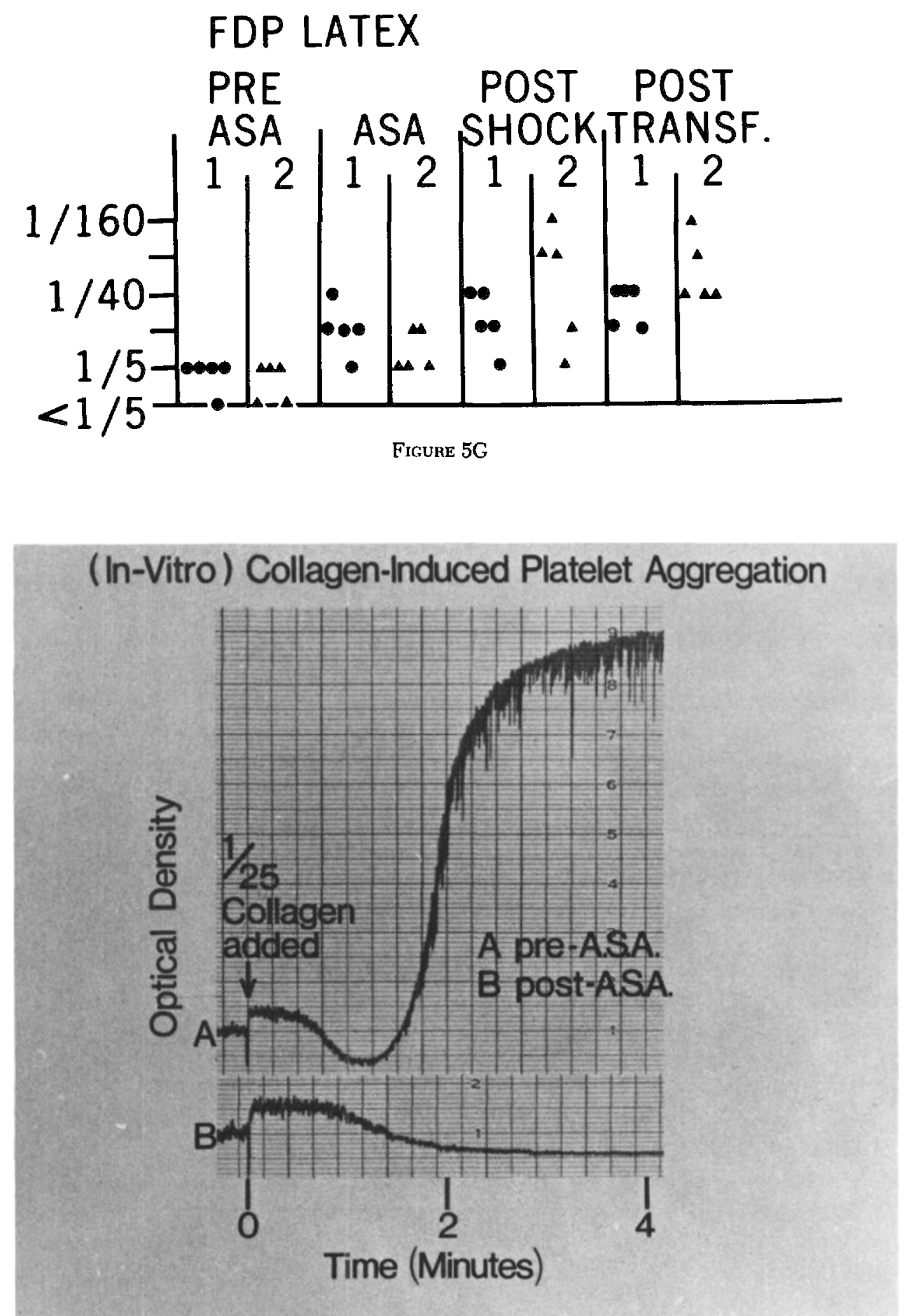

FIGURE 6. In-vitro collagen-induced platelet aggregation is markedly reduced after aspirin (ASA) administration (from 88 divisions to zero). This blood was taken about one hour after the dogs were given aspirin through the stomach tube. 


\section{Discussion}

The coagulation studies were consistent with the development of disseminated intravascular coagulation (DIC) during haemorrhagic shock, in both the aspirin and control groups. However, collagen-induced platelet aggregation which predisposes to microemboli in the lung is significantly reduced in the aspirin group. This may explain why the PVR returned to baseline after retransfusion in the aspirin group but remained elevated by 100 per cent in the control group, despite correction of metabolic acidosis with bicarbonate. Kim and Shoemaker ${ }^{10}$ also reported a 100 per cent increase in PVR following haemorrhagic shock in dogs after correction of the $\mathrm{pH}$. The site of action of aspirin and some other common agents on the platelet aggregation reaction is shown in Table II. Aspirin could affect the PVR by preventing mechanical obstruction of pulmonary vessels by platelet aggregates. Aspirin might also prevent a rise in PVR by inhibiting the extrusion of vaso-active platelet components (e.g. prostaglandin E2 and histamine). These results may not apply if aspirin is given intravenously during the shock period. A study is underway with aspirin given intravenously after shock has been induced, a situation more like the clinical one.

The greater degree of metabolic acidosis after retransfusion in the aspirin group (Figure 4) is unlikely to be due to the aspirin itself as the blood levels of 5 to 8 mg per cent are relatively low (toxic aspirin blood levels are over $20 \mathrm{mg}$ per cent in human subjects). Besides, the same degree of metabolic acidosis was observed during late shock in both control and aspirin groups. In the aspirin group retransfusion may have re-opened more vessels than in the control group with consequent release of acidotic blood into the effective circulation. If this is so, it implies a relatively better peripheral perfusion of the aspirin group than of the control group post-transfusion. In support of this view is the finding of a relatively smaller arterial-mixed venous $O_{2}$ c content difference in the control group, suggesting shunting past peripheral tissues. The message here is to give bicarbonate along with blood when resuscitating patients in haemorrhagic shock. The higher $\mathrm{PaO}_{2}$ and lower $\mathrm{PaCO}_{2}$ and $\dot{\mathrm{Q} S} / \dot{\mathrm{Q}}^{\mathrm{T}}$ in the aspirin group after retransfusion can be explained by increased ventilation due to greater degree of metabolic acidosis than in the control group ( $\mathrm{BE}-21$ and -14 respectively).

We considered fluid overload as a cause of the elevated lung water observed in these dogs. However, these dogs had nothing to eat or drink for 16 hours prior to the experiment and the total fluid load given during the experiment was 60 $\mathrm{ml} / \mathrm{Kg}$ over an eight-hour period. Considering blood loss for catheter placement and the lack of CVP elevation we do not feel these dogs were overloaded.

The greater elevation of lung water in the control group ( 25 per cent) than in the aspirin group ( 14 per cent) appears to be related to the higher PVR in the control group. Aspirin by reducing the PVR should be useful in reducing the accumulation of lung water in the post-shock state.

\section{SUMMARY}

Haemorrhagic shock was induced in two similar groups of dogs for two hours. One group received aspilin before shock and the other group served as a control. 
FAMEWO, et al.: ASPIRIN IN HAEMORRHAGIC SHOCK

TABLE II

Platelet Adhesion-Aggregation Reaction and in Vitro inhibitors

\begin{tabular}{|c|c|c|}
\hline Stage & Reation & Inhibitors \\
\hline 1. Induction & $\begin{array}{l}\text { Altered membrane function } \\
\rightarrow \text { "Activated platelets" }\end{array}$ & $\begin{array}{l}\text { Heparin } \\
\text { Anit-Serotonin drugs } \\
\text { Anti-Adrenergic drugs }\end{array}$ \\
\hline 2. Transmission & $\begin{array}{c}\downarrow \text { Cellular Cyclic AMP. \& } \\
\text { Release of membrane Ca }+ \\
\vec{~}+ \\
\text { and reversible aggregation }\end{array}$ & $\begin{array}{l}\text { Prostaglandin } E_{1} \\
\text { Dipyridamole } \\
\text { Chelating agents }\end{array}$ \\
\hline 3. Energy Production & $\begin{array}{c}\text { Activation of Contractile } \\
\text { Protein } \underset{\text { "Contracted" }}{\rightarrow} \text { Platelets }\end{array}$ & $\begin{array}{l}\text { Inhibitors of glycolysis } \\
\text { and oxidative } \\
\text { phosphorylation }\end{array}$ \\
\hline 4. Release & $\begin{array}{c}\text { Extrusion of platelet } \\
\text { components } \\
\rightarrow \text { Irreversible } \\
\text { aggregation }\end{array}$ & $\begin{array}{l}\text { Aspirin } \\
\text { Serotonin } \\
\text { Heparin }\end{array}$ \\
\hline
\end{tabular}

Ref. "Recent Advances in Thrombosis," No. 1, 1973, Chap. 7, Edited by L. Poller.

When blood was retransfused the PVR which was markedly elevated during shock returned to pre-shock value in the aspirin group but was elevated 100 per cent in the control group, despite correction of acidosis. Aspirin reduces collagen-induced platelet aggregation and thereby inhibits the formation of platelet micro-emboli without affecting the coagulation factors. This effect of aspirin is thought to be responsible for the lowering of the elevated PVR to pre-shock values in the aspirin group following retransfusion. Because of the metabolic acidosis associated with the shock state, concurrent administration of sodium bicarbonate is recommended when retransfusing shocked patients with blood. A clinical trial of aspirin in early treatment of shocked patients as well as for prophylaxis in high risk situations is justified.

\section{RÉSUMÉ}

Nous avons produit chez deux groupes de chiens un choc hémorragique d'une durée de deux heures. Les chiens du premier groupe ont reçu de l'aspirine avant le choc, alors que ceux du second groupe ont servi de contrôle.

Les résistances vasculaires pulmonaires qui s'étaient élevées chez tous les chiens durant le choc expérimental revinrent aux valeurs précédant le choc chez les chiens traités à l'aspirine alors qu'elles demeurèrent élevées de 100 pour cent chez les chiens du groupe contrôle, ceci en dépit de la correction de l'acidose.

L'aspirine contrecarre l'augmentation de l'adhésivité plaquettaire en présence de collagène, augmentation qui favoriserait la formation de micro-embolies plaquettaires au niveau du poumon et, ceci, sans toucher les autres facteurs de coagulation. Nous croyons que cela explique le retour aux valeurs initiales des résistances vasculaires pulmonaires chez les chiens recevant ce médicament.

L'administration de bicarbonate avec les transfusions est indiquée chez les patients en choc hémorragique afin de corriger l'acidose métabolique qui existe dans ces états. Nous croyons justifié de faire un essai clinique de l'aspirine dans le traitement précoce du choc et comme élément de prévention dans certaines situations comportant des risques élevés. 


\section{ACKNOWLEDGMENTS}

We gratefully acknowledge the excellent technical assistance of Mr. Colin Kay, Mr. Gerry Carmichael, Mr. Tony DePersis and Mrs. Nancy Bell, of the Anaesthesia Research Laboratory. We also thank Ms. Susan Slack and Mrs. Carol Martin of the Hematology Research Laboratory, St. Michael's Hospital for their cooperation.

This work was supported by the Medical Research Council of Canada grant \#MA 4263 and the Canadian Tuberculosis and Respiratory Disease Association.

Pentobarbitone Nembutal ${ }^{\oplus}$ was supplied by Abbott Laboratories Ltd., and ACD blood packs were supplied by Baxter Laboratories.

\section{REFERENCES}

1. Dhall, D.P., McKenzie, F.N., Arfons, K.E., \& Matheson, N.A. Platelet behaviour in dogs during and after moderate and severe hemorrhage. European Surgical Research 1: 282 (1969).

2. LJungqvist, U., Bergentz, S.-E., \& Leandoer, L. Platelet adhesiveness and aggregability after acute hemorrhage in the dog. Acta Chir. Scand. 137: 1 (1971).

3. Lauterjung, K.L. \& Isselhard, W. Formation and size of platelet aggregates during hypovolemic hypotension in dogs. Angiology 24: 2 ( 1973).

4. Bo, G. \& Hognestad, J. Thrombocytes and pulmonary vascular resistance during hemorrhaic hypotension. Acta Physiol. Scand. $82: 218$ (1971).

5. CoOK \& WEBs Pulmonary involvement in hypovolemic shock. Surgery 64: 85 (1968).

6. Symposium on thrombosis, platelets and anti-aggregating agents. Acta Med. Scand. Suppl. $521(1971)$.

7. Poller Recent advances in thrombosis. 1st ed. Edinburgh: Churchill-Livingstone (1973).

8. DEYKIN Emerging concepts of platelet function. N.E.J.M. 260:3 (1974).

9. Noble, W.H. \& Severinghaus, J.W. Thermal and conductivity dilution curves for rapid quantitation of pulmonary edema. J. Applied Physiol. 32: 770 (1972).

10. Kim, S.I. \& Shommaker, W.C. Role of acidosis in the development of increased pulmonary vascular resistance and shock lung in experimental hemorrhagic shock. Surgery 73: 723 (1973). 